\title{
7 PENYEBAB BANJIR DI WILAYAH PERKOTAAN YANG PADAT PENDUDUKNYA
}

7 Causes Flooding In City Area Which Are Very Densely Populated

\author{
Oleh: \\ P. Nugro Rahardjo \\ Pusat Teknologi Lingkungan, BPPT
}

\begin{abstract}
Abstrak
Di Indonesia pada waktu musim hujan tiba sering kali terjadi banjir di wilayah perkotaan, terutama di daerah yang padat penduduknya. Pemerintah daerah ataupun pusat selalu mengalami kerugian yang sangat besar akibat terjadinya banjir yang meluas dan melumpuhkan segala aktivitas penduduk kota. Begitu banyak permasalahan-permasalahan lingkungan yang dapat menyebabkan banjir dan permasalahan tersebut telah menjadi sangat kompleks. Setelah dikaji secara mendalam dapat dilihat bahwa terdapat 7 (tujuh) penyebab terjadinya banjir, yaitu: Pembangunan yang tidak berwawasan lingkungan; Tidak-adanya pola hidup bersih $d i$ masyarakat umum; Tidak adanya sistem perencanaan dan pemeliharaan drainase kota yang baik; Tidak adanya konsistensi pihak berwenang dalam RTRW (Rencana Tata Ruang dan Wilayah); Tidak adanya upaya konservasi faktor penyeimbang lingkungan air; Terjadinya penurunan muka tanah; dan Curah hujan yang sangat tinggi. Karena itu perlu dilakukan upayaupaya serius untuk mengatasi masalah banjir tersebut yaitu melalui: Konsistensi pembangunan berwawasan lingkungan; Pola hidup bersih di masyarakat; Penerapan konsep "Water front City"; Penerapan konsep "One River One Management"; Pembuatan Resapan; Pencegahan Land Subsidence dengan cara injeksi air tanah dalam; dan Peningkatan koordinasi seluruh stakeholder.
\end{abstract}

Kata kunci: Penyebab banjir, pilihan untuk mengatasi masalah banjir

\begin{abstract}
In Indonesia during the rainy season floods often occur in urban areas, especially in a very densely populated areas. Central or local government has always suffered huge losses due to widespread flooding and paralyze all activities of the city. So many environmental issues that can cause flooding and the problem has become very complex. By doing assessment study deeply it can be seen that there are 7 (seven) causes flooding, namely: there is not environmentally sustainable development; The lack of a clean lifestyle in the general public; The lack of planning and maintenance of good drainage; The lack of consistency from the authorities in Spatial Planning and Regional; The absence of good conservation programs in balancing environmental of water; land subsidence; and very high rainfall intensity. Therefore it is necessary for serious efforts to address the flooding problem through: The consistency in environmentally sustainable development; Clean lifestyle in the community; The application of the concept "Water front City "; The application of the concept " One River One Management "; Making Infiltration; Prevention of Land Subsidence by Groundwater Injection manner; and Improved coordination of all stakeholders.
\end{abstract}

Keywords: Causes flooding, options in handling flood problem.

\section{PENDAHULUAN}

\subsection{Latar Belakang}

Dalam 20 tahun terakhir banyak kota-kota besar di Indonesia yang berkembang sangat pesat. Perkembangan kota tidak mungkin dicegah sejalan dengan tingginya laju pertumbuhan penduduk. Akibatnya permasalahan lingkungan semakin lama akan semakin parah dan telah mengakibatkan bencana bagi penduduk di wilayah perkotaan, terutama yang berpenduduk sangat padat. Salah satu masalah berat yang dihadapi oleh pemerintah daerah dan masyarakat perkotaan adalah banjir. Setiap musim hujan tiba, kota-kota dan daerah di P. Jawa bagian utara selalu menjadi korban bencana banjir. Bahkan banjir yang terjadi pada akhir tahun 2007 dan awal Maret 2008 di DAS (Daerah Aliran Sungai) Bengawan Solo semakin meluas, tidak hanya pada bagian hilir, namun juga pada bagian hulunya. Meluapnya air sungai yang terjadi bisa mencapai beberapa kali dalam setiap musim hujan dan bahkan setiap banjir yang terjadi ada yang berdurasi lebih dari 3 hari lamanya. Demikian juga halnya dengan Ibu 
Kota Jakarta, meluapnya sungai-sungai yang melintas masuk ke Jakarta selalu terjadi pada musim penghujan. Sungai Ciliwung, Sungai Pesanggrahan dan Sungai Krukut adalah contoh sungai-sungai di Jakarta yang selalu meluap dan mengakibatkan banjir yang meluas dalam lingkup daerah aliran sungainya. Pada saat musim hujan tiba curah hujan rata-rata per hari akan meningkat tajam, bahkan berdasarkan pantauan BMKG pada Kamis, 31 Januari dan Jumat 1 Februari 2008 curah hujan di Jakarta Selatan lebih dari $400 \mathrm{~mm}$ (Laporan triwulanan BMKG 2008). Ditambah dengan hujan lebat di daerah hulu (Bogor), maka bencana banjir pada akhir Januari dan awal Februari 2008 waktu itu mengakibatkan banjir besar berdurasi lebih dari 3 hari (Rahardjo, 2008). Akibatnya kerugian yang sangat besar harus ditanggung oleh seluruh komponen, baik masyarakat, sektor swasta maupun pemerintah daerah (Kompas, 1 February 2008). Bencana banjir di Indonesia adalah bencana yang paling besar menimbulkan kerugian bila dibandingkan dengan bencana-bencana alam yang lain.

Melihat bencana banjir yang semakin tahun semakin meningkat, berbagai pihak telah tergerak kembali untuk turut berperan dalam mengatasi permasalahan ini. Pemda DKI Jakarta telah membangun proyek BKT (Banjir Kanal Timur), serta penjadwalan kembali program-program utama yang berkaitan dengan penanggulangan banjir, misalnya normalisasi Sungai Ciliwung sepanjang $19 \mathrm{~km}$ di Segmen 5, yaitu dari Jembatan Tol Jalan TB. Simatupang hingga pintu air di Manggarai pada tahun 2014 (BBWSCC, 2014). Namun segala upaya yang telah dilaksanakan dan yang telah ditargetkan untuk segera dijalankan, ternyata juga tidak mudah untuk dapat digulirkan karena banyak pihak yang memberi kritik dan ingin mengkoreksi skala prioritas yang telah ataupun yang sedang, atau akan segera dilaksanakan. Karena itu untuk dapat lebih memahami masalah banjir ini dibutuhkan suatu cara pikir yang sama dalam memandang permasalahan tersebut dan sekaligus mengetahui cara yang tepat bagaimana mengatasinya. Sungguh penting untuk melihat permasalahan banjir dari berbagai aspek, sehingga dari penyebab-penyebabnya hingga cara mengatasi permasalahannya dapat diuraikan dengan jelas dan akhirnya secara bertahap selayaknya seluruh komponen masyarakat, swasta dan pemerintah harus bekerja bersama dalam penanggulangan masalah banjir ini.

\subsection{Tujuan}

Tujuan dari pengungkapan penyebabpenyebab banjir disini adalah untuk mensosialisasikan akar permasalahan banjir dan mencari solusi yang seoptimal mungkin dalam upaya penanggulangan masalah banjir ini. Dengan ini pula seluruh masyarakat dan juga seluruh instansi pemerintah yang berwenang diajak untuk melakukan pembentukan suatu pola dasar pemikiran yang sederhana dalam memandang permasalahan banjir dan selanjutnya melangkah bersama dalam pelaksanaan program nyata untuk penanggulangan banjir. Dengan melihat dan memahami penyebabpenyebab banjir ini diharapkan seluruh stakeholder dapat juga mengantisipasi segala permasalahan yang menyangkut banjir guna pencegahan terjadinya banjir.

\subsection{Metodologi}

Tahapan kegiatan dalam melakukan kajian penyebab-penyebab banjir, khususnya di wilayah perkotaan yang padat penduduknya adalah sebagai berikut:

> Identifikasi permasalahan banjir secara umum.

$>$ Studi literatur.

$>$ Melaksanakan pengamatan terjadinya banjir di beberapa lokasi.

- Menganalisis hasil pengamatan terjadinya banjir

Merumuskan kesimpulan.

\section{TUJUH PENYEBAB BANJIR}

\subsection{Pembangunan yang Tidak Berwawasan Lingkungan}

Pertumbuhan dan perkembangan kota-kota besar di Indonesia sebenarnya tergolong cukup pesat. Propinsi DKI Jakarta yang merupakan satu propinsi kaya dan menjadi tolok ukur pertumbuhan ekonomi untuk skala nasional, terus menerus melaksanakan pembangunan di segala bidang. Pembangunan perumahan/pemukiman ataupun untuk areal usaha yang terus berlangsung hingga kini, baik pada bagian selatan (hulu) maupun pada bagian hilir (daerah pesisir) seolah tidak pernah berhenti.

Pembangunan apartemen-apartemen mewah berlantai 20 atau lebih dan fasilitas-fasilitas sarana pendukung infrastruktur di sekitarnya, seperti sarana jalan, pertokoan atau pusat perbelanjaan bahkan mengalami percepatan. Pembangunan perumahanperumahan dan sentra-sentra bisnis pasti membutuhkan sarana dan prasarana lainnya, seperti penyediaan lahan dan energi, serta air bersih. Karena itu pembangunan jalan tol atau outer ring road yang mencakup wilayah Jabodetabek terus berkembang, bahkan berpacu dengan laju pertumbuhan jumlah kendaraan bermotor dan daerah-daerah pemukiman baru. Sebaliknya sebagai konsekuensi dari adanya berbagai aktivitas masyarakat tersebut, maka jumlah air limbah yang akan dihasilkan juga akan meningkat. Limbah cair, padat dan gas yang diproduksi oleh 
segala kegiatan manusia ini semakin lama menjadi terasa sebagai masalah baru yang seolah tidak akan terpecahkan, bahkan semakin berat karena terus terakumulasi.

Suatu kenyataan bahwa pelaksanaan pembangunan dan pengembangan yang demikian pesat di Jabodetabek terlihat tidak berwawasan lingkungan. Peningkatan jumlah dan kualitas pemukiman, serta infrastrukturnya tidak diikuti oleh langkah konservasi dan peningkatan potensi daya dukung lingkungan alamnya. Bahkan yang terjadi adalah pemusnahan berbagai keseimbangan alam dan sumber daya alamnya. Sebagai contoh kasus yang paling mudah dilihat adalah pembangunan dan pengembangan kawasan di bagian selatan dari Wilayah Jakarta Selatan. Daerah selatan Jakarta yang seharusnya merupakan kawasan penyangga karena berada pada regional hulu, ternyata tidak mempunyai konsep pembangunan berwawasan lingkungan atau konsep pembangunan yang berkelanjutan. Tiga kawasan elit di Jakarta Selatan, yaitu Kebayoran Baru, Pondok Indah dan Bintaro telah berubah menjadi kawasan sentra bisnis yang tidak mempunyai kaidah keseimbangan alami. Peraturan Daerah yang menetapkan agar RTH (Ruang Terbuka Hijau) mencakup sedikitnya $30 \%$ dan $70 \%$ nya adalah kawasan terbangun, sudah terlanggar dan tidak diindahkan lagi oleh para pengembang kawasan tersebut. Contoh lain yang paling mudah dilihat adalah banyaknya rumah-rumah yang dibangun dengan mewah namun tidak mempunyai sumur resapan. Bagaimana kawasan Pondok Indah, Kebayoran Baru dan Bintaro yang sudah berkembang menjadi kota satelit tidak mempunyai hutan kota dan waduk atau situ-situ resapan air? Bahkan untuk kebutuhan air bersihnya, kedua kawasan tersebut hanya menyedot air tanah dalam yang mutunya sudah bagus dan para pengembangnya tidak melakukan pengolahan air permukaan. Tambahan lagi dalam pengembangan infrastruktur, seperti jalan tol, sebagian besar daerah resapan air yang semula berupa rawa-rawa, sekarang ini sudah diurug dan diperkeras untuk sarana jalan tersebut. Walaupun di kiri dan di kanan jalan tol juga dibangun kali-kali kecil sebagai saluran air atau drainase kota, namun kapasitasnya sangat tidak memadai, sehingga bila terjadi curah hujan agak tinggi akan menyebabkan genangan air (banjir) sebagai akibat dari meluapnya air kali atau selokan tersebut. Sebagai contoh, saluran drainase kota yang dibangun oleh PT. Pembangunan Jaya di kawasan Bintaro mempunyai dimensi lebar 7 meter dan kedalaman 3 sampai 4 meter. Namun pembuatan saluran dengan ukuran yang cukup besar tersebut hanya ada dalam kawasan Bintaro saja. Pada titik outletnya saluran tersebut menjadi kecil dan sempit, yaitu lebar 3 meter dan kedalamannya hanya 2 meter. Secara visual situasi tersebut dapat dilihat pada Gambar 1.

Pada sepuluh tahun terakhir ini bisnis cluster (suatu kelompok kecil perumahan) telah menjadi ladang keuntungan yang sangat besar bagi pengembang-pengembang bisnis perumahan yang berskala kecil. Satu cluster biasanya mempunyai luasan lahan yang lebih kecil dari $1 \mathrm{Ha}$, kemudian dirancang dan dikembangkan kawasan kecil terbatas untuk suatu kelompok perumahan yang terdiri dari 20 hingga sekitar 50 unit rumah. Unit-unit rumah kecil dengan luas bangunan mulai dari $36 \mathrm{~m}^{2}$ hingga $100 \mathrm{~m}^{2}$ lebih tersebut dengan cepat akan terjual dan terbeli oleh masyarakat golongan menengah ke atas.

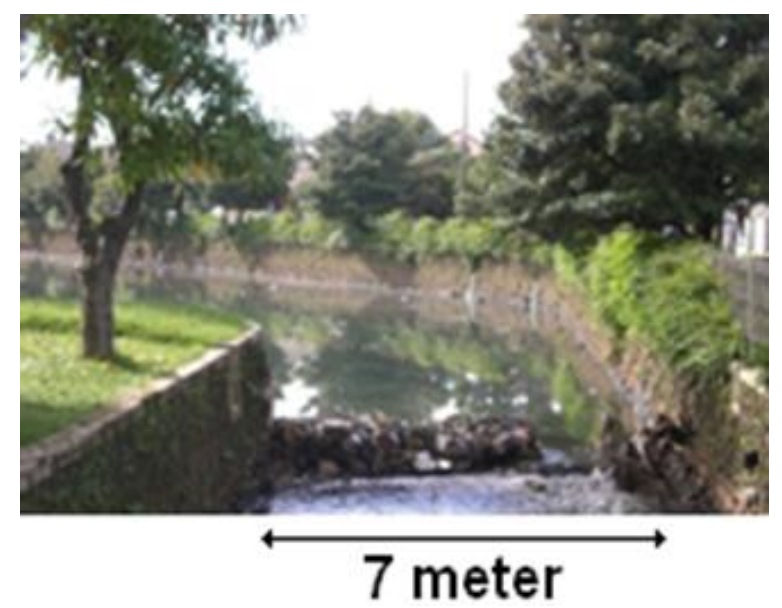

a) Bagian Inlet.

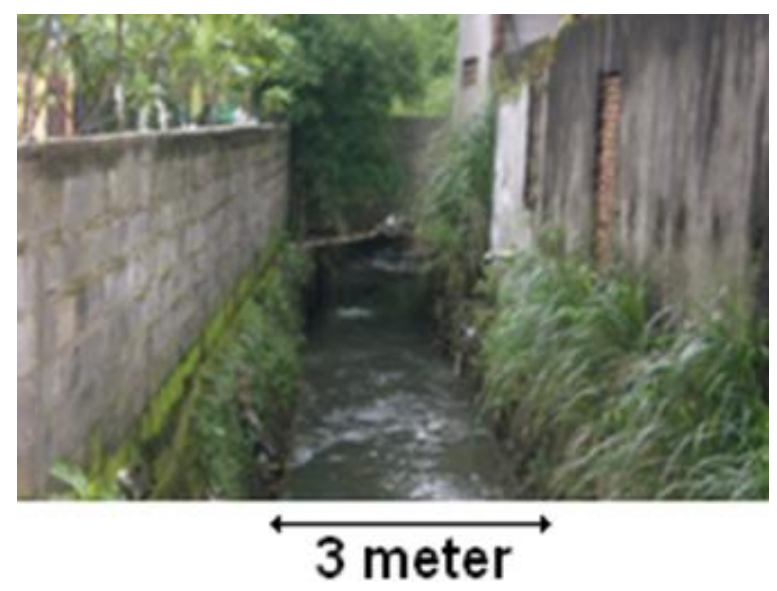

b) Bagian Outlet.

Gambar 1. Saluran Drainase Kota Di Jakarta Selatan Yang Mengalami Penyempitan Dari Lebar 7m Menjadi Hanya $3 \mathrm{~m}$ Pada Bagian Outlet.

Di dalam cluster tersebut jarang sekali disediakan taman-taman kecil sebagai ruang terbuka hijau dan sebagai fasilitas umum atau fasilitas sosial bagi masyarakat yang tinggal didalamnya. Jadi hampir seluruh lahan dimanfaatkan untuk jalan dan rumahrumah tinggal saja, artinya tidak lagi mengikuti kaidah 30\% sebagai RTH (Ruang Terbuka Hijau). 
Pengembangan kawasan perumahan dengan sistem cluster ini sungguh mengancam keterpaduan dan kelestarian keseimbangan lingkungan dalam suatu sistem kawasan perkotaan. Mereka seolah-olah berdiri sendiri-sendiri dan tidak melihat dampakdampak negatif yang ditimbulkannya, terutama terhadap lingkungan sekitarnya. Sering kali cluster dibangun dengan melakukan land filling (peninggian tanah) terlebih dahulu dan kemudian baru pengerasan serta pembangunan unit-unit perumahan untuk hunian. Dengan demikian berarti kawasan cluster tersebut ditinggikan agar terbebas dari genangan air atau pun banjir. Karena itu dampak negatif yang ditimbulkannya adalah bahwa air hujan atau air limbah dari suatu cluster akan mudah mengalir keluar dari sistem cluster tersebut dan area yang di luar kawasan cluster harus menampung air tersebut. Karena terbatasnya daya tampung saluransaluran drainase perkotaan, maka meluaplah air dari saluran drainase hingga kali atau sungai-sungai terdekat, sehingga terjadilah banjir.

Dengan kondisi demikian, maka pada saat curah hujan tinggi pasti akan menyebabkan luapan air yang luar biasa, terutama pada bagian setelah titik outlet tersebut. Dengan kondisi seperti itu, maka semakin banyak kawasan-kawasan lain yang akhirnya menerima luapan air kali yang banjir dan kawasankawasan tersebut menjadi daerah genangangenangan yang seolah-olah terjebak di tengahtengah antara daerah hulu dan hilir. Daerah cekungan-cekungan kecil dengan luasan sekitar $20 \mathrm{Ha}$ yang dahulu merupakan tempat penampungan air, sekarang telah berubah menjadi tempat pemukiman penduduk kelas menengah ke bawah. Daerah-daerah seperti inilah yang selalu menjadi korban banjir paling parah pada saat terjadi curah hujan tinggi. Pada Gambar 2 menunjukkan suasana banjir besar di kompleks perumahan IKPN Bintaro, Jakarta Selatan, yang setiap tahun selalu terjadi.

\subsection{Tidak Adanya Pola Hidup Bersih di Masyarakat}

Sistem pengelolaan sampah atau limbah mutlak harus dimiliki oleh siapapun dan dimanapun, terutama bagi mereka yang melaksanakan pengembangan suatu kawasan baru. Tidak dapat dipungkiri bahwa jumlah penduduk di perkotaan terus meningkat. Peningkatan jumlah penduduk ini membutuhkan tempat pemukiman baru. Karena itu daerah pinggiran kota yang semula (20 tahun lalu) masih mempunyai banyak RTH, saat ini sudah berubah peruntukkannya menjadi daerah pemukiman yang semakin padat. Kepadatan penduduk yang semakin meningkat pun sebenarnya masih dapat ditata rapi dan mempunyai nilai estetika yang tetap baik, asalkan masyarakatnya benar-benar dan sungguh-sungguh mempunyai pola pikir yang baik dan menjaga, serta memelihara lingkungannya dengan sebaik-baiknya.
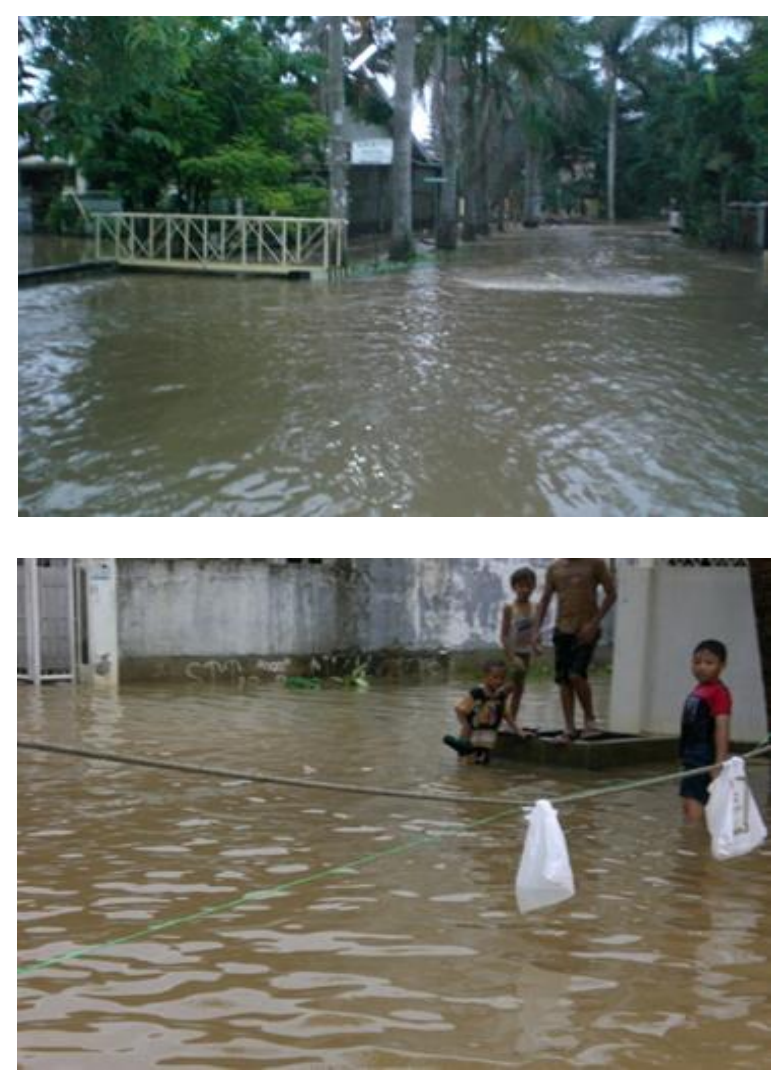

Gambar 2. Kali Pesanggrahan Meluap Dan Menyebabkan Banjir Di Suatu Kawasan Perumahan.

Namun yang terjadi adalah suatu kenyataan yang mengkhawatirkan, yaitu sebagian besar masyarakat Indonesia tidak dapat diatur untuk bersikap tertib dan bersih. Akibatnya limbah (baik padat, cair maupun gas) yang diproduksi oleh masyarakat banyak, ternyata juga tidak dapat terkelola dengan baik.

Sistem drainase yang sudah ada pun tidak dikelola dengan baik. Kali atau saluran-saluran air selalu juga sebagai tempat sampah padat. Tidak adanya budaya bersih dan disiplin tinggi dari penduduk atau warga umumnya dalam hal pengelolaan sampah padat, mengakibatkan masalah yang sangat pelik bagi penyaluran air limbah atau air kotor. Pada saat hujan turun, air yang melimpas di permukaan tanah dan masuk ke saluran drainase tidak dapat optimal terakomodasi oleh sistem drainase yang ada. Sistem drainase tersebut selain tidak terencana dengan baik, juga dipenuhi oleh sampah yang menghambat laju alir pengaliran air hujan yang melimpas tersebut.

Contoh ketidak-pedulian masyarakat terhadap lingkungan yang bersih selalu terlihat di daerah 
pemukiman padat di sekitar Sungai Ciliwung (lihat Gambar 3).

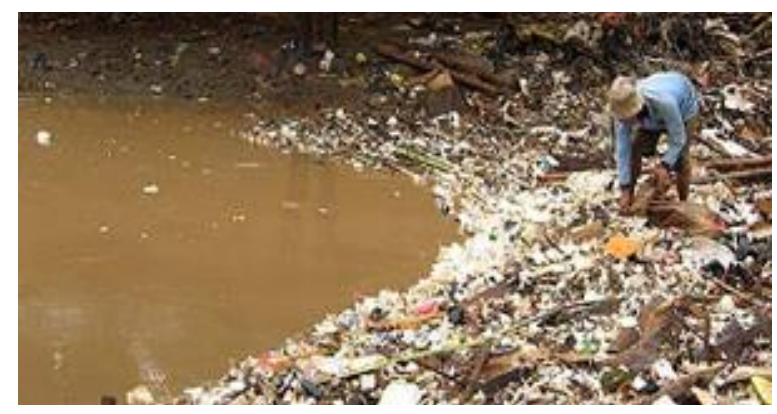

Gambar 3. Sampah Yang Terakumulasi di Sungai Ciliwung di Manggarai, Jakarta Selatan.

Di daerah Manggarai, Jakarta Selatan adalah satu contoh nyata tentang hal tersebut, kebanyakan masyarakat membuang sampah dimana-mana, tidak terkecuali di saluran-saluran drainase kota, sehingga ketika hujan turun dan masuk ke selokan atau jaringan sekunder drainase kota maka sampahsampah akan ikut hanyut dan masuk ke Sungai Ciliwung. Akibatnya adalah pada pintu air Sungai Ciliwung di Manggarai selalu bertumpuk sampah padat, seperti stereoform, plastik bekas kemasan atau pun karton-karton, dahan dan ranting. Sering kali pula terlihat batang pisang yang besar dan kasur yang jelas sengaja dibuang ke Sungai atau ke kali Ciliwung.

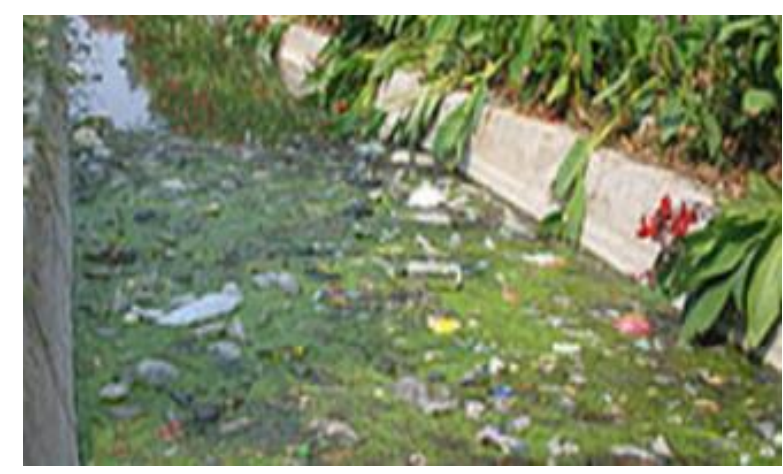

Gambar 4. Sampah Yang Bertumpuk Di Dalam Saluran Drainase Kota.

Hal itu terjadi terus menerus dan sampah yang terakumulasi dapat menyumbat pintu-pintu air, sehingga fungsi dari pintu-pintu air yang sebagai pengatur tinggi muka air dalam bendungannya menjadi tidak ada lagi. Itu semua mencerminkan tidak adanya pola hidup bersih di masyarakat pada umumnya. Dalam keadaan seperti itu, banjir atau meluapnya Sungai Ciliwung sudah menjadi situasi yang sangat biasa dihadapi oleh masyarakat sekitar Manggarai.

\subsection{Tidak Adanya Perencanaan dan Pemeliharaan Sistem Drainase yang Baik}

Tidak adanya sistem drainase yang baik dan terencana untuk suatu daerah atau kota-kota muda yang sedang tumbuh dengan pesat, seperti Kecamatan Pondok Aren, Ciputat, Serpong. Banyak bagian-bagian lahan yang terletak di suatu cekungan yang rendah dan semula adalah daerah resapan atau tangkapan air hujan, sekarang ini telah berkembang menjadi daerah pemukiman yang padat, sehingga setiap kali turun hujan maka air dalam jumlah yang besar akan tergenang dan tidak dapat keluar dari daerah cekungan tersebut. Dengan demikian masalah banjir menjadi masalah sistem yang semakin kompleks. Sistem drainase berdiri sendiri-sendiri dan tidak terpadu, sehingga bahkan secara bersama-sama akan menimbulkan masalah yang sama, yaitu banjir. Permasalahan tersebut ditambah dengan banyaknya jembatan yang dibuat rendah, sehingga sampahsampah yang hanyut akan mudah tertambat di bawah jembatan dan air sungai meluap ke daerah bantaran kali. Perawatan atau pemeliharaan saluran drainase juga tidak pernah atau sangat jarang dilakukan. Pendangkalan terjadi di sepanjang saluran drainase dan bahkan kali atau sungai sebagai badan air penerima dan sampah menumpuk di beberapa titik di sepanjang kali tersebut.

\subsection{Tidak Adanya Konsistensi Pihak Berwenang Dalam RTRW}

Berkaitan dengan butir kedua di atas, Pihak PEMDA (Pemerintah Daerah Kabupaten/Kota atau bahkan sampai tingkat Propinsi) harus mempunyai ketegasan dalam hal peruntukkan lahan yang sesuai dengan RTRW (Rencana Tata Ruang Wilayah) atau dulu dikenal dengan RUTR (Rencana Umum Tata Ruang). Penyusunan tata ruang dari pihak Pemda juga masih belum menerapkan konsep pembangunan berwawasan lingkungan atau sustainable development. Perencanaan pengembangan wilayah masih terlalu memihak pada para pelaku bidang ekonomi. Tak heran jika yang ditonjolkan sematamata hanya pesatnya perkembangan industri, kawasan niaga dan pemukiman elit. Paradigma ini harus diubah dan mengarah kepada kepentingan pelestarian lingkungan. Hanya dengan pelestarian lingkungan, maka akan dapat menjamin kehidupan yang layak untuk anak cucu dan generasi mendatang. 


\subsection{Tidak Adanya Upaya Konservasi Faktor Penyeimbang Lingkungan Air}

Perambahan lahan-lahan basah atau bantaran kali/sungai menjadi pemukiman merupakan gejala umum yang semula dibiarkan berlangsung sedikit demi sedikit dan akhirnya akan semakin mempersempit alur kali atau sungai. Daerah bantaran kali atau sungai yang kemudian dirambah oleh masyarakat liar untuk dijadikan pemukiman tempat tinggal. Demikian juga halnya dengan lahan rawa yang memang berada pada daerah yang rendah dan pada saat hujan selalu menjadi tempat tergenangnya air. Seharusnya kawasan rawa selayaknya dilestarikan dengan sistem perawatan yang baik, sehingga akan dapat dijadikan penampungan air hujan dan sekaligus daerah resapan yang akan dapat menjaga keseimbangan lingkungan air di sekitarnya. Namun sering kali terjadi daerah rawa-rawa justru dimanfaatkan secara komersial, misalnya untuk kompleks perumahan atau pun pertokoan. Banyak pengembang-pengembang kecil yang membangun kompleks perumahan terbatas (cluster) tanpa perencanaan yang matang untuk sistem drainasenya. Daerah-daerah yang semula rawa diurug hingga ketinggian yang di atas atau lebih tinggi dari daerah sekitarnya, kemudian baru dibangun unit-unit rumahnya dengan jalan lingkungan dan saluran-saluran drainase yang mengutamakan pembuangan air ataupun sampah ke luar kawasan clusternya.

Dengan perlakuan-perlakuan seperti tersebut di atas, maka upaya-upaya untuk konservasi demi menjaga keseimbangan lingkungan air sudah sangat jarang dilaksanakan oleh pihak-pihak yang berwenang. Karena itu tidak situ atau kolam untuk resapan dan penampungan air hujan di kawasan perkotaan semakin lama menjadi semakin sedikit atau bahkan hilang sama sekali.

\subsection{Terjadinya Penurunan Muka Tanah}

Turunnya permukaan tanah (land subsidence) dapat terjadi karena tidak seimbangnya kecepatan pengambilan air tanah dengan kecepatan pengisiannya kembali. Kondisi lapisan yang semula banyak mengandung air tanah mengalami peningkatan kepadatan, karena rongga-rongga kosong yang terjadi akibat pengambilan air tanah dengan cepat, secara alamiah melakukan restrukturisasi yang mengakibatkan berkurangnya rongga-rongga kosong tersebut. Proses pemadatan ini tidak reversible, artinya pengisian kembali ronggarongga kosong dengan air tanah yang baru tidak mungkin sama persis dengan kapasitasnya semula. Sehingga terjadi pengurangan potensi air tanah dan kondisi ini bila tidak ditanggulangi akan menyebabkan kondisi yang kritis, khususnya potensi air tanahnya. Sebagai contoh perbandingan, di kawasan Jalan Sudirman-M.H. Thamrin, dimana banyak gedung-gedung pencakar langit yang mengambil air tanah secara berlebihan, telah terjadi penurunan muka tanah sebesar $90 \mathrm{~cm}$ dalam kurun waktu 25-30 tahun sejak tahun 1970. Dengan demikian bila terjadi hujan lebat dalam waktu yang tidak terlalu lama, kawasan ini dengan cepat akan digenangi air. Di sebagian wilayah Jakarta Utara juga telah terjadi land subsidence, sehingga berada di bawah permukaan Laut Jawa.

\subsection{Curah Hujan yang Sangat Tinggi}

Pada musim penghujan, terutama pada saat puncak bulan basah, maka curah selalu termasuk tinggi. Di Jakarta dan sekitarnya telah sering terjadi banjir besar yang dapat dikatakan mempunyai periodik tertentu, yaitu lima tahunan. Tahun 2002 telah terjadi banjir besar sebagai akibat dari turunnya hujan selama 2 hari penuh. Curah hujan pada bulan Februari 2002 tersebut (selama 2 hari) telah mencapai lebih dari 400mm. Kemudian lima tahun berikutnya, yaitu tahun 2007 curah hujan yang turun pada tanggal 1 dan 2 Februari 2007 di beberapa stasiun penangkar hujan menunjukkan angka 339 mm (Kompas, 3 Februari 2007). Curah hujan tersebut tertinggi selama 10 tahun terakhir dan untuk wilayah di Jabodetabek. Dengan demikian curah hujan tersebut memang luar biasa. Pada hari yang sama, curah hujan di daerah Bogor dan Depok justru sangat kecil, yaitu hanya $16 \mathrm{~mm}$. Dapat dibayangkan bila di Bogor dan Depok juga terjadi hujan yang deras selama 2 hari atau lebih secara berturut-turut. Kalau itu yang terjadi maka sebagian besar daerah hilirnya, seperti Tangerang, Bekasi dan Jakarta akan tenggelam jauh melebihi banjir besar pada tahun 2002 dan 2007.

Awal tahun 2014 di bulan Januari dan Februari telah terjadi banjir besar di DAS Bengawan Solo (Bojonegoro) dan DAS Citarum (Kota \& Kabupaten Bandung). Penyebab utamanya adalah curah hujan yang di atas rata-rata. Pada perioda tersebut hujan turun secara terus menerus selama 3 hari, dan mengakibatkan meluapnya sungai di kawasan yang rendah dan merupakan cekungan.

\section{PENANGGULANGAN MASALAH BANJIR}

Penanggulangan masalah banjir harus melihat sistem kesimbangan air untuk suatu kawasan atau wilayah tertentu. Daya tampung suatu kawasan tertentu atau DAS terhadap air hujan harus dilihat berdasarkan keseimbangan siklus hidrologinya.

Pada Gambar 5 jelas terlihat bahwa kuantitas air hujan yang turun akan terbagi merata, yaitu ada 
yang terinfiltrasi atau meresap ke dalam tanah dan ada yang melimpas di atas permukaan tanah dan akan terus mengalir melalui saluran-saluran drainase tersier, sekunder dan akhirnya masuk ke dalam sungai yang akhirnya mengalir ke laut. Karena itu dalam penanggulangan banjir prinsip keseimbangan siklus air dan daya tampung alamiah di suatu kawasan atau DAS tertentu harus di kelola dengan sebaik-baiknya.

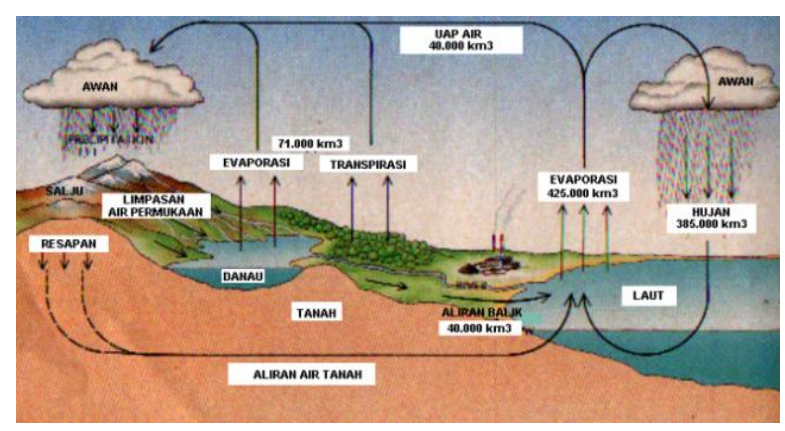

Gambar 5: Siklus Hidrologi secara umum

\subsection{Konsistensi Penerapan Pembangunan Berwawasan Lingkungan}

Perbaikan dan Pemeliharaan sistem drainase secara menyeluruh dari daerah hulu sampai hilir. Hal ini perlu koordinasi antar kabupaten atau bahkan antar propinsi, khususnya dalam penyusunan RTRW yang berwawasan lingkungan. Perlunya penyediaan dan pengelolaan areal bantaran kali atau sungai atau bahkan langkah penertiban. Penerapan suatu batasan luas lahan yang boleh dibangun, yaitu sebesar 70\%, sebenarnya juga sudah mencukupi sebagai salah satu syarat untuk mencegah berkurangnya daya tampung suatu kawasan terhadap air hujan yang turun dengan curah secara maksimal. 30\% RTH harus pula ditaati oleh semua komponen pemanfaatan lahan terbuka. Perlunya menjaga kawasan hijau di daerah hulu sudah menjadi keharusan dan kompensasi-kompensasi sebagai gantinya penutupan lahan terbuka dengan cara pengerasan dan pendirian bangunan di atasnya harus pula terus digalakkan. Salah satu bentuk kompensasi yang sering kali dilaksanakan adalah pembuatan waduk resapan atau sumur resapan yang mempunyai kapasitas sesuai dengan daya tampung dari seluas lahan yang tertutup oleh bangunan.

\subsection{Pola Hidup Bersih}

Mencontohkan dan mensosialisasikan budaya atau pola hidup bersih. Gerakan ini tentu saja harus dilakukan dahulu oleh pemerintah daerah setempat, misalnya dengan melaksanakan program-program pemberdayaan masyarakat dengan dasar pola hidup bersih. Gerakan tersebut lebih diaplikasikan lagi pada peningkatan sistem pengelolaan sampah padat dalam masyarakat pada umumnya.

\subsection{Penerapan Konsep "Water Front Villages",}

Penerapan konsep Water Front Villages, yaitu menempatkan sungai atau kali berikut areal bantarannya sebagai halaman muka rumah. Dengan menempatkan sungai sebagai halaman muka, maka akan timbul niat dan kepekaan masyarakat untuk lebih memperindah wajah depan rumah tinggalnya masing-masing. Sebaliknya, bila rumah membelakangi sungai, maka cenderung sungai dijadikan tempat pembuangan sampah padat, limbah cair dan tak terurus. Lihat contoh-contoh yang sudah banyak diterapkan di negara maju, dimana rumahrumah mempunyai teras yang menghadap ke sungai dengan pemandangan panorama gemericik aliran sungai yang sangat teduh dan alami.

\subsection{Penerapan Konsep "One River One Management",}

Penerapan konsep One River One Management, yaitu dengan melihat keseimbangan alam air (hidrological world equilibrium). Konsep satu sungai satu pengelolaan dasarnya adalah pengelolaan keseimbangan air untuk suatu kawasan DAS yang sering juga dikenal sebagai Satuan Wilayah Sungai (SWS). Dengan sistem pengelolaan DAS ini, maka tidak ada lagi kepentingan hanya untuk satu batas otonomi daerah. Konsep ini menembus kewenangan kekuasaan otonomi daerah demi terciptanya suatu keseimbangan alam yang asri dan sekaligus yang dapat menunjang kebutuhan hidup manusia itu sendiri. Konsep ini telah dijalankan oleh Pemerintah Indonesia, namun belum dapat berjalan secara penuh dan optimal. Berdasarkan PP No. 93 Tahun 1999 dan yang kemudian disempurnakan lagi menjadi PP 46 Tahun 2010, Perum Jasa Tirta I dan II adalah satu bukti nyata keseriusan pemerintah Indonesia dalam melaksanakan konsep One River One Management. Perum Jasa Tirta bertugas secara khusus untuk mengelola pemanfaatan air dan sumber daya air suatu DAS (Daerah Aliran Sungai), baik secara kualitas maupun kuantitas untuk memenuhi kebutuhan air bagi segala keperluan masyarakat luas. Perum Jasa Tirta I mencakup daerah kerja DAS Brantas dan DAS Bengawan Solo, sementara itu Perum Jasa Tirta II mencakup daerah kerja DAS Citarum. Pada area kerja Perum Jasa Tirta II telah dibangun 3 bendungan besar untuk mengendalikan aliran sungai Citarum, yaitu Waduk Jatiluhur, Cirata dan Saguling. Pengoperasian ketiga 
waduk ini telah berjalan sangat baik, namun memang tantangan permasalahan yang lain juga tidak mudah untuk diatasi dengan cepat. Pengelolaan kawasan hulu merupakan kunci agar air hujan yang turun di daerah pegunungan tidak dengan cepat melimpas dan meluncur langsung mengalir ke sungai, tetapi dapat berinfiltrasi masuk ke dalam tanah dan mengisi sungai-sungai bawah tanah (Confined Aquifer). Dalam rangka menjaga kelestarian daerah hulu, karena itu Perum Jasa Tirta II juga harus berkoordinasi dengan pihak pengelola hutan lindung di G. Papandayan dan G. Malabar.

\subsection{Pembuatan Resapan}

Salah satu upaya yang sangat baik dalam pencegahan banjir di daerah perkotaan yang padat penduduknya adalah pembuatan sumur resapan di setiap rumah dan kawasan niaga atau bisnis. Dalam Peraturan Gubernur (PERGUB) DKI Jakarta Nomor 68 Tahun 2005 yang merupakan revisi Peraturan Gubernur DKI Jakarta tentang sumur resapan yakni Peraturan Gubernur DKI Jakarta Nomor 115 tahun 2001, jelas menyatakan bahwa siapa pun yang melakukan pengerasan dan penutupan lahan terbuka hijau seluas $1 \mathrm{~m}^{2}$, maka harus dibuat sumur resapan yang mempunyai volume sebesar 40 liter. Sebagai contoh saja, bila seluruh unit rumah di suatu kompleks perumahan yang mempunyai 500 unit rumah dan setiap rumahnya mempunyai sumur resapan air hujan yang bervolume $4 \mathrm{~m}^{3}$, maka akan dapat tertampung air sebanyak $2000 \mathrm{~m}^{3}$.

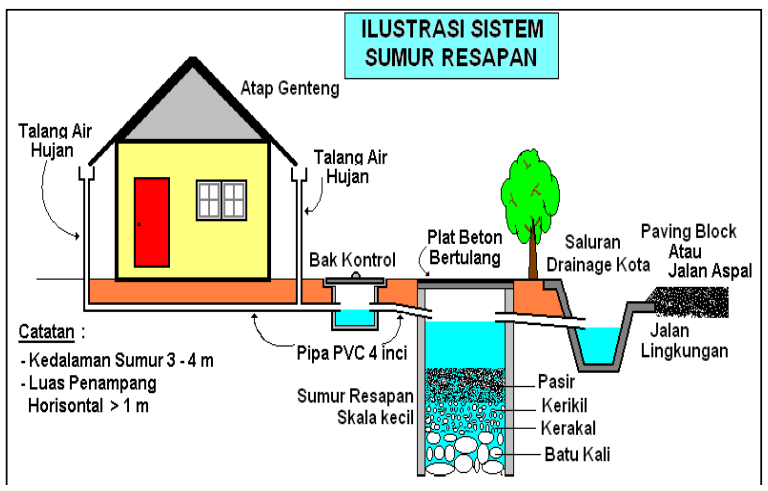

Gambar 6: Sketsa suatu sistem penerapan sumur resapan untuk air tanah dangkal atau lapisan air tanah yang tidak tertekan (Unconfined Aquifer).

Apabila seluruh rumah dimanapun berada mempunyai sumur resapan, hal itu akan menjadi kekuatan yang andal tidak saja untuk menanggulangi banjir tetapi sebagai gerakan menabung air tanah untuk air bersih. Seperti juga dengan pentingnya sumur resapan di daerah pemukiman, demikian juga halnya dengan upaya pembuatan situ atau semacam bendungan sungai (lengkap dengan sistem pintu airnya atau kanal) di beberapa titik lokasi untuk pengendalian debit aliran air yang melimpas dipermukaan tanah dan yang kemudian masuk ke aliran sungai/kali.

Pada Gambar 6 diilustrasikan sketsa suatu sistem sumur resapan untuk air tanah dangkal atau untuk air tanah yang tidak tertekan (unconfined aquifer).

\subsection{Pencegahan Land Subsidence dengan Cara Ground Water Injection}

Pencegahan terjadinya land subsidence dapat dilakukan dengan ground water injection. Injeksi air tanah ini lebih diarahkan pada lapisan air tanah dalam. Injeksi air tanah dengan kualitas air yang memenuhi syarat tertentu harus dilakukan dengan segera, baik pada daerah hulu maupun hilir. Konsep sumur resapan sebenarnya hampir sama dengan ground water injection, namun proses peresapannya dilakukan secara alamiah atau dengan cara gravitasi biasa. Berbeda dengan sistem injeksi, dimana pemasukan air tanah ke dalam lapisan-lapisan penyimpan air tanah dilakukan dengan tenaga pompa. Hal ini diperlukan untuk melawan atau mencegah terjadinya restrukturisasi lanjut yang dapat menyebabkan kebuntuan permanen dari rongga-rongga lapisan batuan pasir kasar yang berada pada kedalaman batas air tanah tertekan (Confined Aquifer).

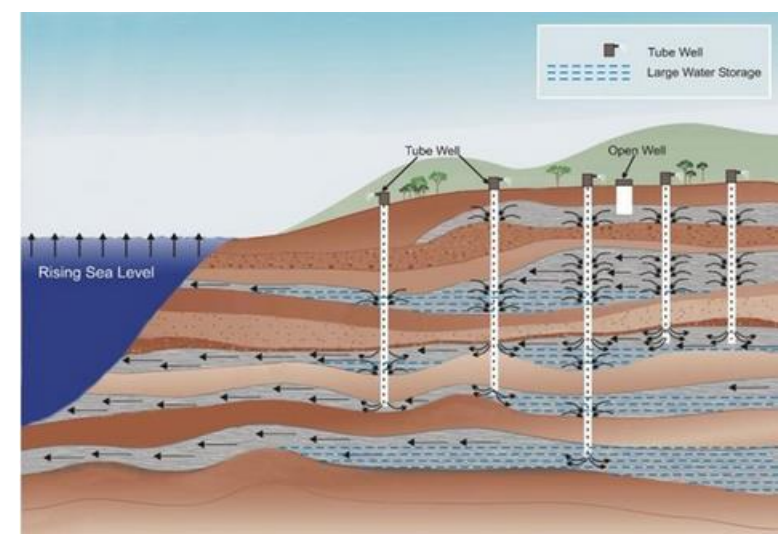

Gambar 7: Ilustrasi beberapa lapisan air tanah dalam yang mungkin dilakukan Ground Water Injection.

Pada gambar di atas diilustrasikan ada air tanah dalam (deep ground water) yang berada berlapislapis dengan perbedaan kedalamannya masingmasing. Dengan menginjeksikan air (dengan kualitas yang memenuhi syarat tertentu) ke dalam lapisanlapisan tersebut, maka rongga-rongga yang berisi air akan terus terjaga agar tidak pernah kosong atau berubah strukturnya. Dengan demikian potensi air tanah dalam akan dapat terus dijaga dan bahkan 
mungkin ditingkatkan, serta dapat mencegah terjadinya penurunan muka tanah (land subsidence).

\subsection{Peningkatan Koordinasi di antara Seluruh Stakeholder}

Karena permasalahan banjir ternyata sangat kompleks, maka pihak Pemerintah Daerah sudah mulai melakukan koordinasi dengan pihak-pihak lain, seperti swasta (para pengusaha pengembang), LSM dan juga masyarakat pada umumnya. Dengan peningkatan koordinasi dan bahkan sampai ke pendanaan pelaksanaan program-programnya, maka permasalah banjir ini akan dapat teratasi setahap demi setahap.

\section{KESIMPULAN DAN SARAN}

Secara umum dapat disimpulkan bahwa permasalahan banjir, khususnya di Daerah perkotaan yang padat penduduknya ini disebabkan oleh karena buruknya sistem manajemen atau pengelolaan DAS (Daerah Aliran Sungai). Permasalahan yang telah terlanjur menjadi besar ini bahkan menjadi semakin kompleks. Baik aparat Pemda dari tingkat Kabupaten sampai tingkat Kelurahan dan juga didukung oleh pihak swasta, LSM-LSM, serta masyarakat telah menyadari bahwa permasalahan banjir ini harus diurai berdasarkan faktor-faktor penyebabnya dan selanjutnya tahap demi tahap program penanggulangan banjir diprioritaskan untuk dilaksanakan dengan komitmen yang kuat dari seluruh stakeholder.

Disarankan dalam upaya penanggulangan masalah banjir di wilayah perkotaan yang padat penduduknya, Pemerintah Daerah dan Pemerintah Pusat harus mampu berperan sebagai pelopor yang memiliki kiat-kiat khusus dan komitmen yang kuat untuk memberi contoh, serta memacu kesungguhan dari seluruh stakeholder. Untuk mengatasi masalah banjir ini jelas membutuhkan dana yang sangat besar dan waktu yang lama. Sebagai contoh program yang sangat baik adalah Program Normalisasi Sungai Ciliwung yang dilaksanakan oleh BBWSCC (Balai Besar Wilayah Sungai Ciliwung Cisadane) pada tahun 2014. Dengan membuat urutan prioritas atau programprogram unggulan yang disetujui oleh berbagai pihak dan semua stakeholder, maka diyakini bahwa masalah banjir ini akan teratasi secara perlahan namun pasti.

\section{DAFTAR PUSTAKA}

- Annonim 3, "Curah Hujan Di Jakarta", Kompas, 3 Februari 2007, Jakarta.

- Annonim 2, "Data Curah Hujan Harian Bulan Januari-Februari 2007", Kantor Stasiun Penakar
Hujan Meteo, Pondok Betung, Jakarta Selatan, 2008.

- Rahardjo P. Nugro, "Laporan Pengkajian Sistem Pengelolaan Sungai", Pusat Teknologi Lingkungan, 2008.

- Annonim 1, "Banjir Melumpuhkan Jakarta", Kompas, 1 February 2008, Jakarta.

- Annonim 4, "Kegiatan Normalisasi Kali Ciliwung Dari Pintu Air Manggarai Sampai Jembatan Tol TB Simatupang", Balai Besar Wilayah Sungai Ciliwung Cisadane (BBWSCC), Direktorat Jenderal Sumber Daya Air, Kementerian Pekerjaan Umum, Jakarta, 2014.

- Peraturan Gubernur (PERGUB) DKI Jakarta Nomor 68 Tahun 2005 tentang Sumur Resapan. 